\title{
Merger and Acquisition Patterns and Trends: An Evidence of an Emerging Economy, Turkey 2014-2018
}

\author{
Waleed M. Alhanhanah'1, Murat Akbalik², Abisola Leah Akosile \\ ${ }^{1}$ Institute of Social Sciences, Okan University, Istanbul, Turkey \\ ${ }^{2}$ School of Banking and Insurance, Marmara University, Istanbul, Turkey \\ ${ }^{3}$ Institute of Graduate Studies and Research, European University of Lefke, Lefke, North Cyprus \\ Email: alwaleedmusaed@gmail.com, makbalik@marmara.edu.tr
}

How to cite this paper: Alhanhanah, W.M., Akbalik, M. and Akosile, A.L. (2019) Merger and Acquisition Patterns and Trends: An Evidence of an Emerging Economy, Turkey 2014-2018. Open Access Library Journal, 6: e5837.

https://doi.org/10.4236/oalib.1105837

Received: October 8, 2019

Accepted: October 25, 2019

Published: October 28, 2019

Copyright $\odot 2019$ by author(s) and Open Access Library Inc.

This work is licensed under the Creative Commons Attribution International License (CC BY 4.0).

http://creativecommons.org/licenses/by/4.0/

\begin{abstract}
This study aims to provide contemporary and comparative analysis on mergers and acquisitions ( $M \&$ As) activities that Turkish companies are involved between 2014-2018, by analyzing trends in deal number, deal volume activity and characteristics, and an attempt to explore the challenges, issues and implications opposing companies in M \& As in Turkey. The study follows a qualitative method for data collection and analysis, using secondary data and the annual merger and acquisitions review reports of Deloitte 2014-2018. The paper will display probable outcomes of these events in the future and their effects on firms and government or economical conjuncture. This paper will add to related research in the future. The findings show that $M \&$ As in Turkey had fluctuated in that period in deal number and activity. Merger and acquisition data and figures in the selected period of the study show a positive record for instance deal number was 1275 transactions were announced, with accumulated total value US $\$ 64$ billion.
\end{abstract}

\section{Subject Areas}

Business Analysis

\section{Keywords}

Acquisition and Merger, Emerging Economy, Emerging Market, Turkey

\section{Introduction}

Turkey had passed by a series of crises that caused a heavy impact upon its 
economy structure and business firm development during 1990s and during the hard crisis 2000/2001. Due to these hard times of financial crisis and recession, companies had to find resilient mechanisms to secure their survival and adjust their strategies in order to manage proponent crises of uncertainty. In the pre-liberalization period during the 1980s in Turkey, corporate reform had not been common as a new strategy and policy in the corporate world. During the early 1990s M \& A, takeovers, strategic alliances and joint ventures in the corporate sector were a dynamic mechanism on a large number of corporate reorganization in the arise of competition from multinational companies as well as developing new opportunities. This phenomenon was highly increased due to the wake of liberalization and capitalist economy measures that reduced the government's control, and restrictions which enhanced investment and reregulates corporate structure to grow, diversify and modernize the operations by resorting to mergers, acquisition, takeovers and the adoption of technological trends.

The main objective of this paper is to identify the trends, issues and challenges that involved in $\mathrm{M} \& \mathrm{~A}$ activities in the emerging market Turkey over the period 2014-2018. There had been fewer studies done regarding Turkish M \& A, therefore; this study will add to the Turkish literature review. Mergers and acquisitions play an important role for businesses all over the globe. Past researches show that Merger and Acquisition transactions were commonly spread in developed markets [1]. Primarily, it was in the United States, the UK, and continental Europe, but now many companies started using M \& A worldwide, including emerging and developing markets to achieve several goals of the organizations to succeed in the market.

Mergers and acquisitions are a significant source of external growth and corporate improvement. For more than a century merger and acquisition have been applied as a significant part in strategic management practices and research [2]. The major motives of companies going for $\mathrm{M} \&$ As are to achieve greater market power, lowering cost of capital, thus decreasing the threats associated with the growth of a new product or service, magnify efficiency through economies of scale and scope and reshape a firm's competitive scope. Mergers and Acquisitions have been an essential and important strategy to fulfill organizational efficiency and growth by creating synergies, obtaining assets, lessening costs and expanding to new markets [3]. Mergers and acquisitions lead to improved profitability for both manufacturing and service sectors [4]. M \& As activities help companies to secure the benefits of bigger market share and cost efficiency, and these benefits are demonstrated by the superior post-merger performance of the acquiring entities [5].

\section{Literature Review}

Literature assumes that $\mathrm{M} \& \mathrm{~A}$ create synergies, generate economies of scale and scope, expands operations in new geographical markets, diversification of activities, and finally cost and risk minimization, as a result leading to growth max- 
imization, enhanced financial and operational performance. The key motive behind $\mathrm{M} \& \mathrm{~A}$ is to accomplish synergy by incorporating two or more business entities into a combination with an increased competitive advantage [6]. The origin of the word synergy was derived from the Greek word synergos, which means working together [7]. In business policy literature, synergy is frequently described as one plus one is more than two, that's the whole is greater and more than the sum, where two companies will generate greater value more than separate entities or individual companies.

Merger and acquisition have been adopted by companies mostly as a growth strategy and as an approach for business internationalization. M \& As had received high usage and importance of abundant studies, which have been discussed in several fields including; finance, economy, management, accounting [8] [9] [10]. In today's world of globalization and fast technological changes, mergers and acquisitions have become a convincing strategic growth for companies, to expand business geographical operations, accomplish economies of scale, and achieve financial performance [11].

Merger is a strategic activity in which two firms combine their stocks, assets, and liabilities and only one survives and the merged corporation ceases to exist [12]. Merger is an absorption of one company by another company, including all its assets, stocks and liabilities, after a merger the acquired company ceases to exist as a separate individual entity. Whereas, acquisition was defined as the process of one corporation buys the shares of another company and the acquired company is no longer the owner of the firm [13]. Acquisition is a purchase of another business, where a sales contract is executed under which the acquirer company assumes all or some of the target company's assets and stocks.

Merger and acquisition are applied by numerous large corporations around the world for their profit expansions, gaining access to technology, human capital, improving product mix and reaching a new geographic market [14]. Merger is a form of strategic alliance whereby two firms work together in pursuance of similar objectives [15]. M \& As have received great attention in the literature. Literature assumes that there is a positive effect of $M \&$ As on firm performance, and increase in productivity and profitability [16]. M \& A is corporate strategy aimed precisely as a means for promoting future growth and creating sustainable value [17].

Finance theories propose both positive as well as negative effects of mergers and acquisitions on corporate firms' performance. According to the theory of merger and acquisition, successful $M \& A$ deals maximize the profitability of the acquirer corporations. Companies pursue M \& As to increase their market power, efficiency, expansion, diversification, internationalization, and to achieve financial and managerial synergies [18]. Through M \& As corporations are able to get rid of the problem of limitation by efficient use of limited resources [19]. Mergers and acquisitions are important mechanisms to improve the competitiveness of a firm and performance of firm managers [20]. Various corporations 
consider mergers and acquisitions an ideal policy to expand their businesses and diversify their ownership boundaries [21]. Mallikarjunappa and Nayak [22] summarized that target firm shareholders attain positive abnormal returns ranging from 27 percent to 37 percent by examining a sample of 227 Indian firms, which received takeover bids during 1998-2007. On the other hand, according to the managerial theory of a firm, mergers and acquisitions have a negative impact on the acquiring firm's financial performance and profitability [23]. Bhabra and Huang [24] concluded that merger and acquisition deals do not significantly influence the profitability and financial performance of corporations. The agency theory, presume that in undertaking $M \&$ As deals, the acquiring firm managers might act in their own interest rather working to maximize shareholder wealth [25].

There are a number of studies that discussed the Turkish market of merger and acquisition. Günay Bendaş [26] examined the firm level market returns for Turkish acquirers and found a significant long-term effect of acquisitions on market returns. Ilarslan \& Aşıkoğlu [27] investigated 17 acquisitions by Turkish public firms in 2004-2005 and found evidence about positive improvements in financial performance of these acquirers. Mandacı studied $14 \mathrm{M} \& \mathrm{~A}$ transactions performed in Turkey between 1998 and 2000 and revealed that the liquidity ratios and asset turnover ratios for target firms declined after these deals [28]. [29] Selçuk analyzed cross-border M \& A deals and found that the effect of these transactions on the operating performance of target firms was insignificant. Arslan and Şimşir [30] concluded that the operating performance of target firms involved in $\mathrm{M} \&$ As deteriorates after these transactions. Selcuk and Yilmaz [31] evaluated the effect of $\mathrm{M} \&$ As from both an economic and accounting perspective, they found that the acquirer companies are negatively affected by $\mathrm{M} \&$ As deals activities. Hekimoglu and Tanyeri [32] compared the abnormal returns following acquisitions deals in Turkey with the ones in Europe and United States they found that the abnormal returns in Turkey are positive but small compared to the returns in US and Europe.

\subsection{Synergies in Merger and Acquisition}

Synergy was defined as a combination of resources that generate greater value together than separately by increasing profits and minimizing costs, is the central conception in the M \& A literature [33]. Many scholars support the significance of synergy as a merger motive and the main driver of value creation in $M$ \& As and the supreme reason for M \& A success [34] [35]. Synergy was defined as the behavior of integral, aggregate, whole systems unpredicted by behavior of any of their components taken separately from the whole [36]. An integrated analysis of the strategic management and the finance literature emphasizes that synergy is the primary motive of $M \&$ As, these studies conclude that $M \&$ As can create value for the combined firms and synergy can have a positive effect on targets, acquirers and total gains [37]. 
The major motive behind M \& A is to accomplish synergy by mixing two or more business entities into a combination with an increased competitive advantage [6]. Synergy increases market power and financial strength, reduces threats, and leveraging capabilities [38]. M \& A can also create three kinds of synergies through combination and customization of resources differently, results from economies of scale and scope help firms to accomplish more profits and efficiency [11]. Operating synergy can be achieved when a firm with good product line is acquired by a firm with good marketing skills. Synergy can be attributed to more power over the rivals, reduced competition that result in competitive advantages and core competencies which lead to higher profit margins [11]. Financial synergy can be hypothesized in the context of investment opportunities and internal cash flows. The impact of merger or acquisition on the cost of capital of the combined company is called the concept of financial synergy, where the cost of internal financing will be lowered. Managerial synergy, where acquisition of management talents, experts and capabilities could be a source of potential gain in $\mathrm{M} \& \mathrm{~A}$ activity [11].

\subsection{The Historical Role of Mergers and Acquisitions Waves}

The historical waves of mergers have been a factor of economic transformational life in the United States since the late $18^{\text {th }}$ century. More than 50 percent of the acquisitions that performed between 1890s and 1990s took place during one of four merger waves [39]. Melicher and Ledolter [40] stated that the first merger wave was during 1890-1905 that comprised of horizontal mergers, which created industrial giants in steel, mining, oil, and transportation etc. The second wave has been related to both the economic recovery after World War I and the start of the great depression 1929. As a result of enlarged control over limited resources and operating economies, the second wave was formed as vertical mergers between companies with former connections of buyer-seller relationships during the 1920s.

The third wave resulted in major economic conglomerates between unrelated companies during the 1960s and 1970s arose with the economic recovery after the World War II was identified in the United States, the UK, and Continental Europe came into prominence in economic life. The fourth wave, took place during 1981 to 1989 that arose with the recovery after the 1970s recession, financial innovations, industrial transformation, reported in the United States, the UK, Europe, and Asia in that period. The fourth wave took place during 1980s which resulted in hostile acquisitions, and bond financing [41]. Finally, the fifth wave, known as mega-merger and mega-fusions, also identified in the United States, the UK, Continental Europe, and Asia between 1993 and 2001[42]. The fifth wave characterized with globalization of national economies, burst of internet bubble, technological advancement, stock market boom, state deregulation of liberalizing economies and privatization [42].

In today's globalized world economy, corporate and enterprise internationali- 
zation is increasing around the world, breaking down border trade barriers and fostering global competitive state and international business strategy. The $21^{\text {st }}$ century witnessed a tremendous powerful mergers and acquisitions activities in the developed and developing countries as well. Over the past two decades M \& As grew as a result of globalized economies boom, rapid growth of economies, and economic policies reform measures on the potential of the international markets. Companies have to face tough challenges with their competitors and rivals to survive by forming new strategic norms to strengthen and secure their existence as alliance, merger and acquisition. Companies look for a secured investment whether a merger, acquisition or alliances in stable markets with stable economy, to maximize profits, increase market share, reduce cost, improve innovation, and create a competitive advantage.

\subsection{A Global Prospective of Merger and Acquisition}

Since the year 2000, till the first quarter of 2019, more than 790,000 thousand transactions have been announced worldwide with a known value amounting to 58 trillion USD. In 2018, deal value was positively increased better than the year 2017 was increased by $4 \%$ with a volume to (3.9) trillion USD, while deal number has decreased by $8 \%$ about $(50,000)$ transactions, where it was in 2017 $(52,000)$ transactions, with amount of (3.7) trillion USD [43]. Figure 1 covers deal numbers and volume worldwide, pointing out trends of that period, as explained the fluctuations and volatility of $\mathrm{M} \& \mathrm{~A}$ number and value due various global shake up in the world economy as it happened in 2001-2002 that devastating financial crisis impacted world economy and the M \& A sharply dropped from the previous years.

Global M \& A achieved highest in volume in the year 2007 with a volume of (4.92) trillion USD due to high recovery and stability of world economy. Global financial crisis 2008-2009 that hit the world, caused a sharp decline in M \& A activities, and the following four years witnessed a slow merger and acquisition during that period. Global M \& As recovered positively upward during 2014 and 2015, whereas there was a slight decline in the year 2016-2017, but in 2018 M \&

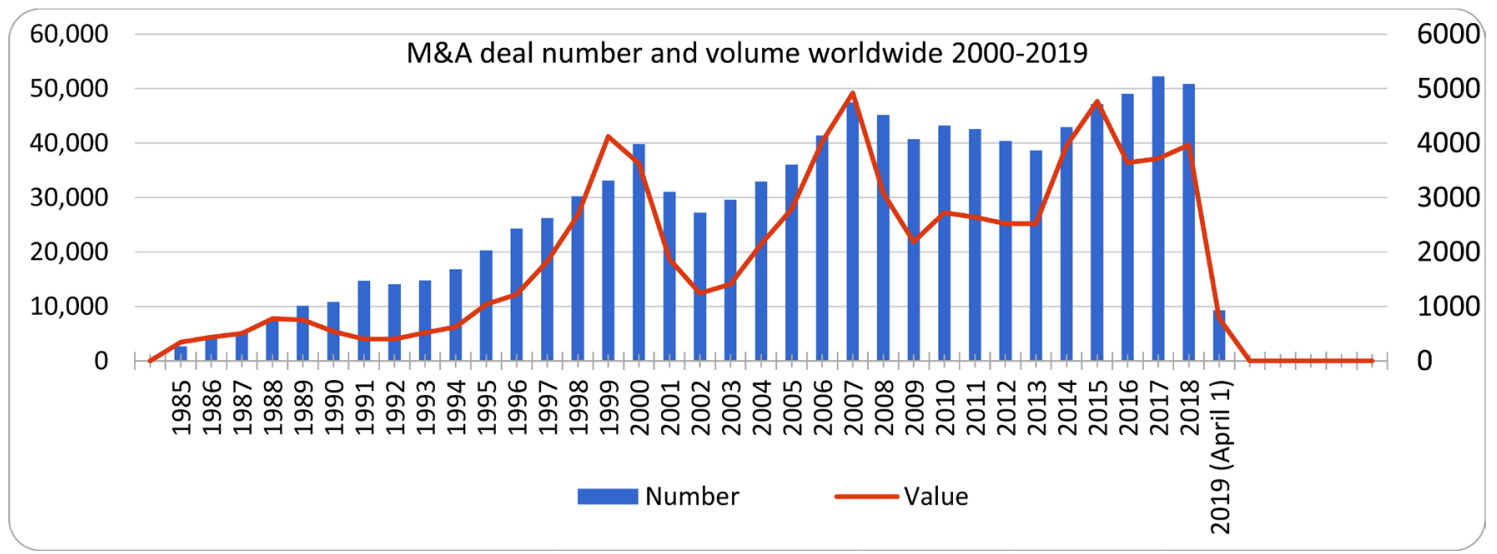

Figure 1. M \& A deal number and volume worldwide, institute of merger and (IMAA) 2019. 
A performed better. The expectation for the year 2019 is optimistic as the indicators so far show a positive tendency of the first quarter reaching almost $(10,000)$ deals with an expected value of (782) billion USD.

\subsection{An Overview of the Turkish Merger and Acquisition 2014-2018}

Over the past three decades, Turkey witnessed a significant increase in $M$ \& As flow to the country, especially after the devastating crisis that happened during 2000-2001. Turkish government after the 2000 crisis had restructured the regulatory environment, liberalizing economy, attracted foreign direct investment and capital flow in and out of the country, improves the country's technological infrastructure, corporate governance. These trends made the country a significant $M$ \& A player among the other rapidly growing emerging markets, and the country has witnessed a substantial growth in M \& A activities. Turkey is one of the fastest growing emerging markets in the world, has enjoyed a dramatic rise in $\mathrm{M} \& \mathrm{~A}$ activity as well. There has been a great transformation in the Turkish economy that pushed several Turkish companies to engage in $M \&$ As to internationalize their business operations, attracting foreign capital flows in and out of Turkey, increase exports/imports, were playing drivers of the Turkish economic growth [44].

In this paper, the Deloitte annual reports (Table 1) were used to analyze activities of mergers and acquisitions in Turkey, covering the trends and positions M \& A transactions, value of the respective period, contribution share by domestic and foreign investors, and the highest deals in that period. Turkey's enjoys a high growth potentials, good infrastructure, an attractive market position, smart advancement in technology and relatively favorable macroeconomic indicators, therefore; Turkey is an attractive option for investment [45]. The year of 2014 witnessed the largest accumulation of annual deal volume and contribution over the remaining years of the study. Local Turkish investors succeeded in a total annual volume of US $\$ 10.1$ billion, and through 123 deals, whereas the foreign investors were involved in 113 deals amounting to US $\$ 7.9$ billion including

Table 1. Merger and acquisitions in Turkey in USD Billion (bn) (Deloitte Reports) 2014-2018.

\begin{tabular}{|c|c|c|c|c|c|}
\hline Year & 2014 & 2015 & 2016 & 2017 & 2018 \\
\hline Deal Number & 234 & 245 & 246 & 295 & 256 \\
\hline Deal Volume & US $\$ 18.0$ bn & US $\$ 16.4$ bn & US $\$ 7.3$ bn & US $\$ 10.3$ bn & US $\$ 12.0 \mathrm{bn}$ \\
\hline Privatization/ & $\$ 5.9$ bn & $\$ 1.8$ bn & $\$ 0.7$ bn & $\$ 0.6$ bn & $\$ 1.0 \mathrm{bn}$ \\
\hline Share in Total & $33 \%$ & $11 \%$ & $10 \%$ & $6 \%$ & $8 \%$ \\
\hline Share in Total & $44 \%$ & $70 \%$ & $52 \%$ & $53 \%$ & $63 \%$ \\
\hline \multirow{2}{*}{ Financial Investors } & $12 \%$ deal Vol/ & 19\% Deal Vol/ & $22 \%$ Deal Vol/ & 25\% Deal Vol/ & $8 \%$ Deal Vol/ \\
\hline & $15 \%$ Deal No & $21 \%$ Deal No & $41 \%$ Deal No & $49 \%$ Deal No & $41 \%$ Deal No \\
\hline \multirow{2}{*}{$\begin{array}{l}\text { Largest Deal Value/ } \\
\text { Share in Total }\end{array}$} & US $\$ 2.7$ bn & US $\$ 30$ bn & US $\$ 687.8 \mathrm{mn}$ & US $\$ 1.4$ bn & US $\$ 3.2$ bn \\
\hline & (Yenikoy \& Kemerkoy & (Finansbank) & (Mars Entertainment & (OMV Petrol Ofisi) & (Denizbank) \\
\hline
\end{tabular}


estimates for undisclosed values [46]. In terms of total contribution share, Turkish investors represented $66 \%$ of the total annual contribution, while, foreign investors represented $44 \%$ of the total annual contribution deal volume.

Whereas in 2015, Turkish investors suffered a decline in deal volume comparing to the previous year 2014 which generated US $\$ 4.9$ billion, through 120 deals; however, foreign investors deal volume grew up amounting US \$11.5 billion, through 125 deals [47]. Turkish investors represented only $30 \%$ of the total annual contribution share, while, the foreign investors represented $70 \%$ of the total annual contribution deal volume in 2015. The annual deal volume and contribution of M \& A in 2016 suffered the worst year of the whole period of the study. That year shows a huge decline in both Turkish and foreign annual deal volume during 2016. Turkish investors amounted only US \$3.5 billion, through 155 deals representing $63 \%$ of the total annual deal number, on the other hand foreign investors involved only in US \$3.8 billion, through 93 deals making 37\% of the total annual deal number [48]. The total annual contribution share, Turkish investors were involved in $48 \%$ of the total annual contribution share, while foreign investors represented $52 \%$ of the total annual contribution share.

The year 2017 witnessed a recovery of increasing the deal volume, where Turkish investors generated a total annual volume totaling US $\$ 4.8$ billion, including estimates on undisclosed values through 228 deals, making up $77 \%$ of the total annual deal number. Foreign investors in 2017 were involved in 70 deals contributed to US $\$ 5.5$ billion including estimates of undisclosed values, making up to making up to $23 \%$ of the total annual deal number [49]. Turkish investors were involved in $47 \%$ of the annual total contribution share of deal volume, while foreign investors were involved in $53 \%$ of the deal volume. Whereas, by the year 2018 witnessed a positive recovery that resulted better than the previous year of 2016 in total annual deal volume, but Turkish investors were lagged behind foreign investors with a total annual deal volume of US \$4.4 billion, through 182 deals, making $71 \%$ of the total annual number, while foreign investors outperformed domestic investors amounting to US $\$ 7.6$ billion through 74 deals representing $29 \%$ of the total annual deal number, including estimates of undisclosed values [50]. Total contribution in 2018, Turkish investors were involved in $37 \%$ of the total annual contribution, however; foreign investors involved $67 \%$ of the total annual contribution volume.

The highest acquisition deals in the respective period of the study was realized in the financial services sector (FSS) 2018 amounted to US \$3.2 billion, Denizbank with a total share (27\%). The second largest was in 2015 with a value of US $\$ 3.0$ billion it was a (FSS), Finansbank of a total share (18\%). Whereas, the third largest activity was in Energy with a value of US \$2.7 Billion in 2014 (Yenikoy \& Kemerkoy Power Plants) with a total share (15\%). The fourth largest activity was US \$1.4 billion in 2017 (OMV Petrol Ofisi) of a total share (14\%), whereas; the lowest activity was US $\$ 687$ million in 2016, (Mars Entertainment Group) with a total share of $(9 \%)$. 


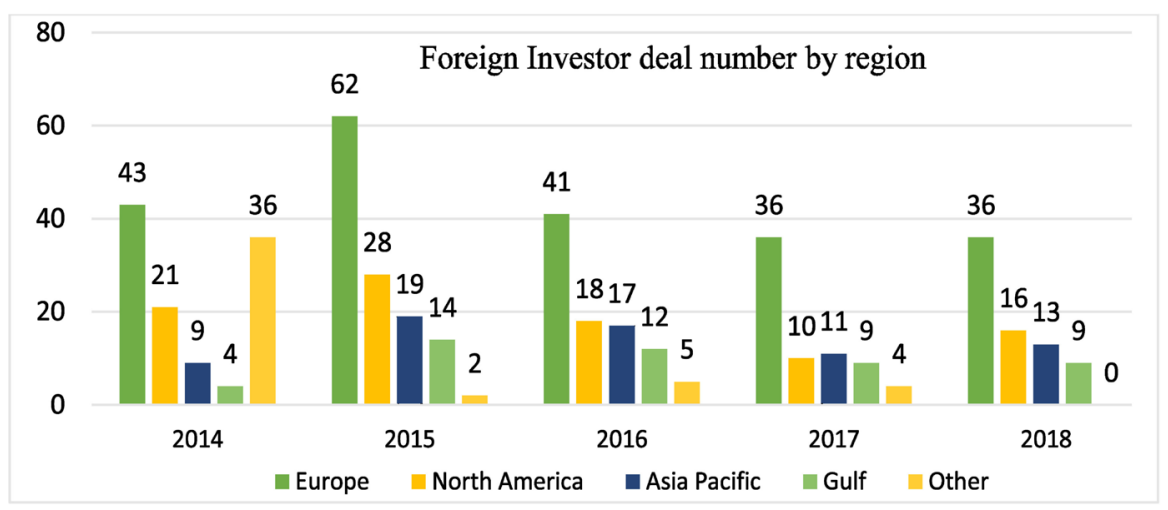

Figure 2. Foreign investor deal number by region.

Foreign deal number by origin were outperformed by the European region block the whole time period as shown above in Figure 2, where the European investors topped foreign investors in deal numbers for the past five years. Whereas, North American investors were the second number accounted by investors' transactions deals, followed by Asia Pacific and Gulf region respectively all the time period.

\section{Discussion and Conclusions}

Mergers and acquisitions have become progressively broad-based phenomenon, and their numbers and value are growing intensely throughout the globe. Turkey is one of the fastest growing emerging markets in the world, has enjoyed a higher growth in M \& A activity as well. The Turkish government started liberalizing the economy during 1990s and after the devastating crisis 2001-2002, attracted foreign direct investment and capital flow in and out of the country. Turkish Government improves the country's technological infrastructure, and reregulates corporate policies measures in addition to the country's attractive location which connects Asia and Europe. These trends made the country a significant $M$ \& A player among the other rapidly growing emerging markets, and the country has witnessed a substantial growth in $\mathrm{M} \& \mathrm{~A}$ activity in terms of deal numbers and values. Several Turkish companies engage in $M \&$ As activities, diversified their deals, internationalize their business operations, increase exports/imports, those were playing drivers of the Turkish economic growth. Therefore, merger and acquisition witnessed a positive surge from foreign and domestic investors during the past thirty years.

However, M \& A activities in Turkey fluctuated and impacted by the issues happened globally either positively or negatively. Whereas, the period of the study 2014-2018, fluctuated in the deal number and activity volume due to different imbalanced economic indicators. The country passed by a political transitional election the year 2014 that has some impact. A major issue was that the country affected by the regional conflict of neighboring countries. Another issue, is the political tension between Washington and Ankara that resulted in some sanctions and adding higher taxes on trade exports to Turkey. Similarly, other 
challenges of increased inflation rate in the country resulted unsettled the value of the lira compared to exchange rate against US dollar, where the local currency lost 40 percent of its value comparing to US dollar in August 2018 [51], and the inflation in Turkey reached 16.3 percent in 2018 [52]. The above mentioned are some of the challenges and issues that impacted the $M \&$ As activities in Turkey during the time period of the study. Nevertheless, the period of the study shows a positive activity in last two years 2017/2018 indicate a positive interest of foreign and local investors in Turkish companies. $M$ \& As in Turkey is expected to grow positively in 2019 as the country's economy is steadily growing, where Turkish GDP for 2018 reached 769 US billion [52], that is a positive indicator of a healthy and prosperous economy.

\section{Conflicts of Interest}

The authors declare no conflicts of interest regarding the publication of this paper.

\section{References}

[1] Zheng, N., Wei, Y., Zhang, Y. and Yang, J. (2016) In Search of Strategic Assets through Cross-Border Merger and Acquisitions: Evidence from Chinese Multinational Enterprises in Developed Economies. International Business Review, 25, 177-186. https://doi.org/10.1016/j.ibusrev.2014.11.009

[2] Bauer, F. and Matzler, K. (2014) Antecedents of M \& A Success: The Role of Strategic Complementarity, Cultural Fit, and Degree and Speed of Integration. Strategic management journal, 35, 269-291. https://doi.org/10.1002/smj.2091

[3] Grant, R.M. (2016) Contemporary Strategy Analysis: Text and Cases Edition. John Wiley \& Sons, New York.

[4] Schiffbauer, M., Siedschlag, I. and Ruane, F. (2017) Do Foreign Mergers and Acquisitions Boost Firm Productivity? International Business Review, 26, 1124-1140. https://doi.org/10.1016/j.ibusrev.2017.04.003

[5] Pandya, V.U. (2018) Mergers and Acquisitions Trends-The Indian Experience. International Journal of Business Administration, 9, 44-54. https://doi.org/10.5430/ijba.v9n1p44

[6] Porter, M.E. (1985) Competitive Advantage. Free Press, New York.

[7] Goold, M. and Campbell, A. (1998) Desperately Seeking Synergy. Harvard Business Review, 76, 131-143.

[8] Tao, F., Liu, X., Gao, L. and Xia, E. (2017) Do Cross-Border Mergers and Acquisitions Increase Short-Term Market Performance? The Case of Chinese Firms. International Business Review, 26, 189-202. https://doi.org/10.1016/j.ibusrev.2016.06.006

[9] Banerjee, T. and Nayak, A. (2015) Comparing Domestic and Cross-Border Mergers and Acquisitions in the Pharmaceutical Industry. Atlantic Economic Journal, 43, 489-499. https://doi.org/10.1007/s11293-015-9476-0

[10] Gregory, A. and O’Donohoe, S. (2014) Do Cross Border and Domestic Acquisitions Differ? Evidence from the Acquisition of UK Targets. International Review of Financial Analysis, 31, 61-69. https://doi.org/10.1016/j.irfa.2013.09.001

[11] Kumar, B.R. (2019) Mergers and Acquisitions. In: Wealth Creation in the World s Largest Mergers and Acquisitions, Springer, Cham, 1-15. 
https://doi.org/10.1007/978-3-030-02363-8_1

[12] Gaughan, P.A. (2010) Mergers, Acquisitions, and Corporate Restructurings. John Wiley \& Sons, New York. https://doi.org/10.1002/9781118269077

[13] Sudarsanam, P.S. (1995) The Role of Defensive Strategies and Ownership Structure of Target Firms: Evidence from UK Hostile Takeover Bids. European Financial Management, 1, 223-240. https://doi.org/10.1111/j.1468-036X.1995.tb00018.x

[14] Srivastava, R.K. (2018) Managing Mergers and Acquisitions in Health Care: A Case Study in the Pharmaceutical Sector. International Journal of Healthcare Management, 1-13. https://doi.org/10.1080/20479700.2017.1422337

[15] Anyanwu, S.A. and Agwor, T.C. (2015) Impact of Mergers and Acquisitions on the Performance of Manufacturing Firms in Nigeria. African Research Review, 9, 156165. https://doi.org/10.4314/afrrev.v9i2.12

[16] Tao, F., Liu, X., Gao, L. and Xia, E. (2017) Do Cross-Border Mergers and Acquisitions Increase Short-Term Market Performance? The Case of Chinese Firms. International Business Review, 26, 189-202. https://doi.org/10.1016/j.ibusrev.2016.06.006

[17] Calipha, R., Tarba, S. and Brock, D. (2010) Mergers and Acquisitions: A Review of Phases, Motives, and Success Factors. In: Advances in Mergers and Acquisitions, Emerald Group Publishing Limited, Bingley, West Yorkshire, 1-24.

[18] Petitt, B.S. and Ferris, K.R. (2013) Valuation for Mergers and Acquisitions: Valuation 2. FT Press, Upper Saddle River, NJ.

[19] Weston, J.F., Chung, K.S., Hoag, S.E. (2006) Mergers Restructuring and Corporate Control. Prentice Hall, Upper Saddle River, NJ.

[20] Huh, K.S. (2015) The Performances of Acquired Firms in the Steel Industry: Do Financial Institutions Cause Bubbles? The Quarterly Review of Economics and Finance, 58, 143-153. https://doi.org/10.1016/j.qref.2015.03.001

[21] Dash, A.P. (2013) Mergers and Acquisitions. IK International Pvt Ltd., New Delhi.

[22] Mallikarjunappa, T. and Nayak, P. (2013) A Study of Wealth Effects of Takeover Announcements in India on Target Company Shareholders. Vikalpa: The Journal for Decision Makers, 38, 23-50. https://doi.org/10.1177/0256090920130303

[23] Pillania, R.K., Kumar, S. and Bansal, L.K. (2008) The Impact of Mergers and Acquisitions on Corporate Performance in India. Management Decision, 46, 1531-1543.

[24] Bhabra, H.S. and Huang, J. (2013) An Empirical Investigation of Mergers and Acquisitions by Chinese Listed Companies, 1997-2007. Journal of Multinational Financial Management, 23, 186-207. https://doi.org/10.1016/j.mulfin.2013.03.002

[25] Jensen, M.C. and Meckling, W.H. (1976) Theory of the Firm: Managerial Behavior, Agency Costs and Ownership Structure. Journal of Financial Economics, 3, 305360. https://doi.org/10.1016/0304-405X(76)90026-X

[26] Bendaş, G. and Büşra, F. (2015) The Effects of Acquisitions on Firm Value, Evidence from Turkey.

[27] İlarslan, K. and Aşikoğlu, R. (2012) Birleşme ve satın almaların işletmelerin finansal performansı üzerindeki etkilerinin incelenmesi: Panel veri analizi. Finans Politik ve Ekonomik Yorumlar, 49, 59-78.

[28] Mandac1, P.E. (2005) The Effects of Mergers and Acquisitions on the Financial Structure and Performance of the Firms. Íktisat, Issletme ve Finans Dergisi, 20, 60-67. https://doi.org/10.3848/iif.2005.233ek.0628

[29] Akben-Selçuk, E. (2008) The Impact of Cross-Border Non Target Company Performance: Evidence from Turkey. Economics Bulletin, 13, 1-9. 
[30] Arslan, H. and Simsir, S.A. (2014) Satın Alım Öncesi Ve Sonrası Türk Hedef Şirketlerinin Finansal Performansı (The Financial Performance of Turkish Target Firms Around Acquisitions) İktisat, İșletme ve Finans. https://doi.org/10.3848/iif.2014.345.4251

[31] Akben-Selcuk, E. and Altiok-Yilmaz, A. (2011) The Impact of Mergers and Acquisitions on Acquirer Performance: Evidence from Turkey. Business and Economics Journal, 22, 1-8.

[32] Hekimoğlu, M.H. and Tanyeri, B. (2011) Stock Market Reactions to Mergers of Non-Financial Turkish Firms (Türk Şirket Birleşmelerinin Hisse Senedi Fiyatları Üzerindeki Etkileri). https://doi.org/10.2139/ssrn.1768015

[33] Shaver, J.M. (2006) A Paradox of Synergy: Contagion and Capacity Effects in Mergers and Acquisitions. Academy of Management Review, 31, 962-976. https://doi.org/10.5465/amr.2006.22527468

[34] Kaplan, S.N. and Weisbach, M.S. (1992) The Success of Acquisitions: Evidence from Divestitures. The Journal of Finance, 47, 107-138. https://doi.org/10.1111/j.1540-6261.1992.tb03980.x

[35] Kiymaz, H. and Baker, H.K. (2008) Short-Term Performance, Industry Effects, and Motives: Evidence from Large M \& As. Quarterly Journal of Finance and Accounting, 47, 17-44.

[36] Fuller, R.B. (1982) Synergetics: Explorations in the Geometry of Thinking.

[37] Berkovitch, E. and Narayanan, M.P. (1993) Motives for Takeovers: An Empirical Investigation. Journal of Financial and Quantitative analysis, 28, 347-362. https://doi.org/10.2307/2331418

[38] Carpenter, M.A. and Sanders, W.G. (2007) Strategic Management: A Dynamic Perspective. Pearson Prentice Hall, Upper Saddle River, NJ.

[39] Haleblian, J., McNamara, G., Kolev, K. and Dykes, B.J. (2012) Exploring Firm Characteristics that Differentiate Leaders from Followers in Industry Merger Waves: A Competitive Dynamics Perspective. Strategic Management Journal, 33, 1037-1052. https://doi.org/10.1002/smj.1961

[40] Melicher, R.W., Ledolter, J. and D’Antonio, L.J. (1983) A Time Series Analysis of Aggregate Merger Activity. The Review of Economics and Statistics, 65, 423-430. https://doi.org/10.2307/1924187

[41] McNamara, G.M., Haleblian, J. and Dykes, B.J. (2008) The Performance Implications of Participating in an Acquisition Wave: Early Mover Advantages, Bandwagon Effects, and the Moderating Influence of Industry Characteristics and Acquirer Tactics. Academy of Management Journal, 51, 113-130. https://doi.org/10.5465/amj.2008.30755057

[42] Martynova, M. and Renneboog, L. (2008) Spillover of Corporate Governance Standards in Cross-Border Mergers and Acquisitions. Journal of Corporate Finance, 14, 200-223. https://doi.org/10.1016/j.jcorpfin.2008.03.004

[43] Institute for Mergers, Acquisitions and Alliance (2019). https://imaa-institute.org/mergers-and-acquisitions-statistics/

[44] Yıldırım, C. (2017) Turkey' Outward Foreign Direct Investment: Trends and Patterns of Mergers and Acquisitions. Journal of Balkan and Near Eastern Studies, 19, 276-293. https://doi.org/10.1080/19448953.2017.1277084

[45] Ömür, G.A., Tunç, A.Ö. and Düren, A.Z. (2012) Patterns of Mergers and Acquisitions in Turkey in the Era of "New Normal". Procedia-Social and Behavioral Sciences, 58, 1611-1617. https://doi.org/10.1016/j.sbspro.2012.09.1148 
[46] Deloitte (2015) Deloitte Annual Turkish Mergers and Acquisitions Review 2014.

[47] Deloitte (2016) Deloitte Annual Turkish Mergers and Acquisitions Review 2015.

[48] Deloitte (2017) Deloitte Annual Turkish Mergers and Acquisitions Review 2016.

[49] Deloitte (2018) Deloitte Annual Turkish Mergers and Acquisitions Review 2017.

[50] Deloitte (2019) Deloitte Annual Turkish Mergers and Acquisitions Review 2018.

[51] Bloomberg (2018) Turkish Lira Tumbles as Volatility Returns.

https://www.bloomberg.com/news/articles/2018-08-27/turkish-lira-tumbles-as-vola tility-returns-after-holiday-week

[52] World Bank (2018) Turkish Annual Report Review. https://www.worldbank.org/en/country/turkey 